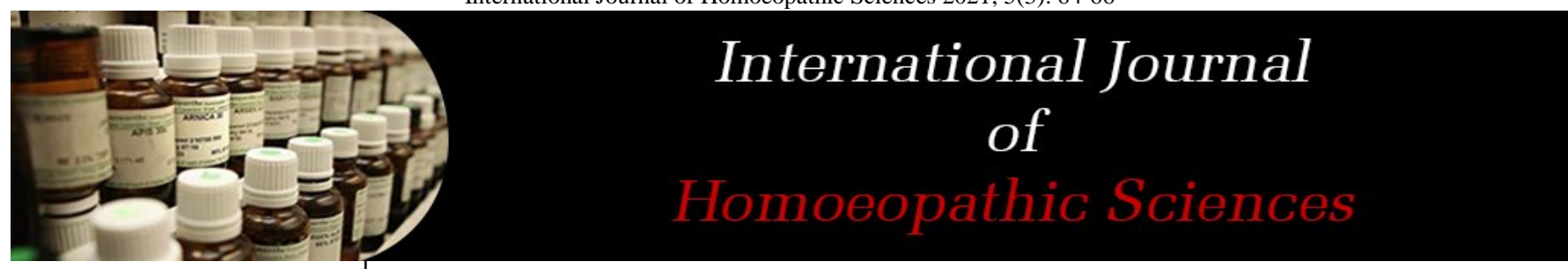

E-ISSN: 2616-4493 P-ISSN: 2616-4485 www.homoeopathicjournal.com IJHS 2021; 5(3): 64-66 Received: 04-03-2021 Accepted: 29-04-2021

Dr. K Rathna Kumari Bhms, Md Materia Medica, Assistant Professor, Department of Homoeopathic Pharmacy, MNR Homoeopathic Medical College, Sangareddy, Telangana, India
Corresponding Author: Dr. K Rathna Kumari Bhms, Md Materia Medica, Assistant Professor, Department of Homoeopathic Pharmacy, MNR Homoeopathic Medical College, Sangareddy, Telangana, India

\title{
Phytochemical action and thereuptic affinity of curcuma longa-homoeopathy medicine
}

\section{Dr. K Rathna Kumari}

DOI: https://doi.org/10.33545/26164485.2021.v5.i3a.403

\section{Abstract}

Curcuma longa beginning echoed from ancient times. It is an herb which is used in different system of medicine. It is known for its religious, medical use. It has different phyto constituents with different pharmacological activity. Study of this drug in homoeopathy helps us to know about its thereuptic activity.

Keywords: Cucurmin, rhizome, thereuptic affinity

\section{Introduction}

Curcuma is very lesser known drug in Homoeopathy which is native of India and south East Asia. It's a plant having both aroma and medicine power. It is used as traditional medicine since ancient times mainly for injuries. It introduced first as dye then as a spice and cosmetic. Commonly known as turmeric but it has many names based on region, like haldi, pasupu, etc., Indian curries without this spice is very rare. It is also used in preparation of biscuits, dairy products etc. cucurmin paper which also known as curcumapapier in German literature is used as indicator in chemical assay of ph indicator ${ }^{[6]}$.

History: Genus name ‘curcuma' came from Arabic word 'kurkum' which means saffron. It is called as Indian saffron. From India it had reached China by 700A.D to East Africa by $1200 \mathrm{AD}$. Other than its use as spice and medicine people in India use it as precious substance during wedding ceremony.

\section{Botanical description}

Botanical name: curcuma longa

Family: zingierbaceae

Common name: Hindi- Haldi, English - turmeric, saffron, Sanskrit- laksmi, harita, Habitat: throughout India

Part used in homoeopathy as medicine - Rhizome

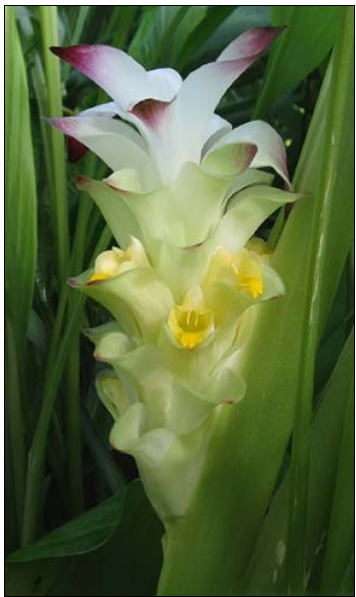

Fig 1: Inflorescence

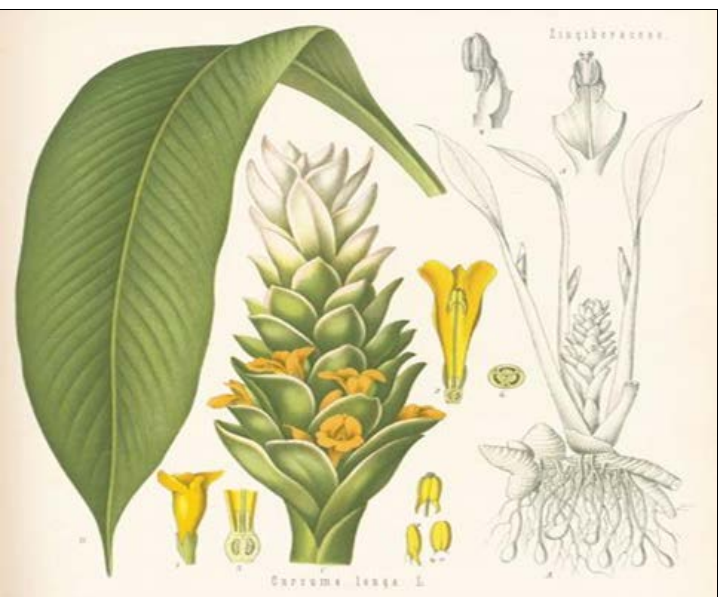

Fig 2: Whole plant 


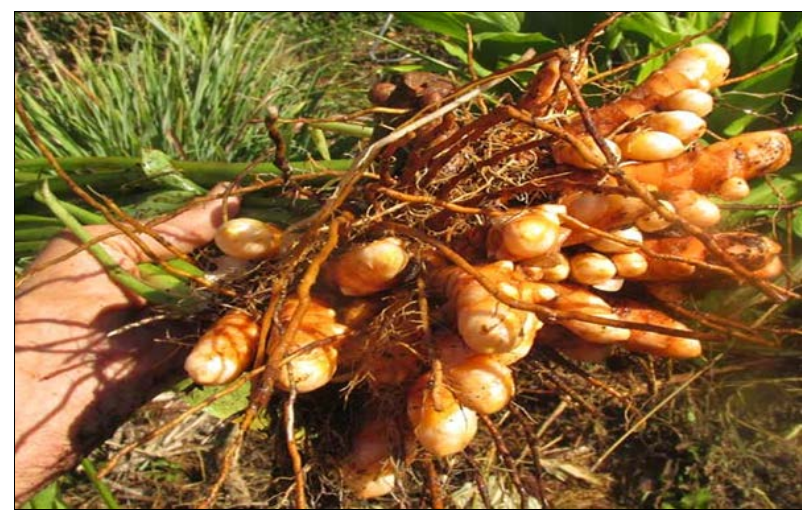

Fig 3: Curcuma rhizome

Turmeric is modified underground stem with distant nodes and internodes growing horizontally. It is perennial herbaceous plant which grows approximately $1 \mathrm{~m}$ in height. Leaves are arranged alternatively in two rows which are further divided in to leaf sheath, petiole, and leaf blade. Inflorescence of turmeric is a central spike of 10-15 cm length. 1-4 flowers are in axil of the bract it opens once at a time. Capsules are produced by Seeds and there will be numerous sunken capsules in an inflorescence. It grows in black and red soils in irrigated and little rainfall places ${ }^{[7]}$. These rhizomes are boiled, dried and then it is grounded to get deep orange- yellow color ${ }^{[16]}$.

\section{Phytochemistry}

Active priciples of turmeric are curcuminoids: it includes curcumin diferuloylmethane, primary active principle responsible for yellow color of turmeric, and its structure determined as diferuloylmethane [1, 7-bis (4-hydroxy-3 methoxyphenyl)-1, 6-heptadiene-3, 5-Dione] in 1910 [11] It exists in enolic form in organic solvents and in keto form in water ${ }^{[6]}$. And others are demethoxycurcumin, and bisdemethoxycurcumin. Volatile oils - tumerone, atlantone, and zingiberene. Sugars, proteins, and resins are also ingriedients in turmeric ${ }^{[1]}$.

\section{Pharmacological action}

Curcumin pharmacological activities includes antioxidant, hepatoprotective, antibacterial, antiviral, antineoplastic, anti-inflammatory, antifungal, antidiabetic, anticoagulant, and cardiovascular protective. The anticancer activity of curcumin is mainly because of its ability to inhibit and or to activate various intracellular transcription factors, by this it regulates the expression of various proteins that participate in tumor growth and development ${ }^{[2]}$. Some study showed that an ethanol extract from $C$. longa will inhibits gastric acid secretion by blocking $\mathrm{H}$ (2) histamine receptors ${ }^{[14]}$. One of limitation of cucurmin is its chemical instability, absence of selective target activity, low bioavailability, water insolubility, limited tissue distribution. Some amount of curcumin escapes the GI tract and most is excreted in feces which will be unchanged. If curcumin enter plasma in limited amounts it could create toxicity, interacts with several proteins which further increase the risk of adverse effects $^{[6]}$.

Thereuptic activity: central council of Homoeopathy had conducted research on this drug. According to it rhizome of curcuma is potentised. 6X triutation is used for drug proving. This is peculiar method in Homoeopathy in which drug is proved on healthy human beings and symptoms are noted. A wide range of symptoms had been showed by turmeric.

\section{Symptoms observed}

Mind: dullness, difficult concentration with forgetfulness, he thinks friends and relatives are against him restless and worries about future.

Head: bursting type of pain in whole right side of head, pricking sensation in right side of eye.

Eyes: burning sensation in eyes with lachrymation, redness of right eye with pain.

Nose: frequent sneezing with watery discharge from nose Face: Itching of right cheek, amelioration on cold application.

Mouth: dryness with white coated tongue.

Tooth: pain on holding cold water in mouth.

Throat: pain in left side amelioration with hot drinks.

Stomach: thirst for cold water whole day for small quantity, feels hungry immediately after eating, has desire to chew betel leaves and smoking

Abdomen: fullness and heaviness, rumbling and distension of abdomen.

Rectum: Constipation, hard and scanty stool

Stool: yellowish, offensive contains undigested particles,

Renal system: increased frequency of urination during night time.

Female: During menses pain in lower abdomen.

Larynx: dry cough, agg at night.

Expectoration: scanty yellow in color, tastes like pus

Chest: pain in right side of chest, agg-night, there will be palpitation with sensation as of weight over sternum

BACK: shifting type of pain in in hip joints with aching pain in sacral region. Agg on changing of posture, feels stiffness in cervical region more on turning head

Extremities: trembling of hands while writing there will be pain in knee and elbow joints better by rest

Skin: Itching all over body without eruptions after taking bath, macular rashes on body.

\section{Conclusion}

Cucurmin which shows huge pharmacological activities in crude form is potentised according to principles of Homoeopathy through which latent form of medicinal power are aroused and exhibits high thereuptic power. With help of its pharmacognosy and pharmamacodynamis we can cure diseases permanently. Hence this review throws light on its thereuptic properties, efficacy to cure carcinoma, ability to act on different organs of body.

\section{References}

1. Amitava Dasgupta. Anti-inflammatory Herbal Supplements in Translational Inflammation 2019;4:6991.

2. Maira Rubi Segura Campos, Armando M. Martín Ortega, Bioactive Compounds, 1st edition, date of publication 2018;5:85-109.

3. Ccrh, new drugs proved by ccr published by central council research of Homoeopathy, New Delhi 16.

4. Erika Ramos-Tovar, Pablo Muriel, Dietary Interventions in Liver Disease, foods, nutrients and dietary supplements, $1^{\text {st }}$ edition, date of publication 2019;9:101-121.

5. Wikipedia.org.curcuma longa. 
6. Indian.spices.com. curcuma longa.

7. Mandal and Mandal-'A Text book of Homoeopathic Pharmacy' third edition, New Central Book of Agency (P) ltd 446.

8. Niranjan mohanty, sujata kumara choudhari, santhosh kumar jena - $a$ double-lind, placebo-controlled Homoeopathic pathoogenetic trial of nanocurcumin 6X 2015;9(3):176-187.

9. Ravindran PN, K nirmal babu, kandaswamy sivaram, turmeric, the genus curcuma, medicinal and aromaticplants-industrial profiles', $1^{\text {st }}$ edition, volume 45 crc press 2007.

10. PS cakraborty, SA Ali, Subhash Kaushik, RK Ray, RP Yadav MK Rai Darshan Singh et al., 'curcuma longa a multicentric clinical verification study 2011;5(1):1927.

11. Samuel Hahnemannn. Organon of Medicine, $6^{\text {th }}$ edition' Indian Books and Periodical Publishers, New Delhi.

12. Susan G, Wynn Barbara J. Fougère, Veterinary Herbal Medicine: A Systems-Based Approach in Veterinary Herbal Medicine, date of publication 2006, 20.

13. CCRH, Vernacular names of plant drugs in Homoeopathi pharmacopeia in India, first edition, CCRH' published by central council research of Homoeopathy, New Delhi 16.

14. blog.honest.com.

15. sciencedirect.com/topics/agricultural-and.../curcumalonga.

16. Herbal material medica.wordpress.com. 